\title{
Honesty Education to Chinese College Students
}

\author{
Ma Hongxin ${ }^{1, a}$ Zhao Yunchang ${ }^{2, b}$ \\ 1Jilin Agricultural University, Changchun Jilin 130118 China; \\ 2 Jilin Agricultural University, Changchun Jilin 130118 China. \\ a2207733@qq.com, b260818740@qq.com
}

\begin{abstract}
Key words: college students honesty education honesty management system honesty surroundings
\end{abstract}

\begin{abstract}
Honesty is an important guarantee for the comprehensive development of contemporary college students. This study analyzes the honesty features of Chinese college students with questionnaire surveys of Jilin Agricultural University students, makes proposals and suggestions based on efforts of establishing moral value, specifying cores of credit and integrity education and clinging to the honesty subject as well as improving the relevant management system and cultivating honesty surroundings. It is supposed that this study will provide theoretical and realistic basis for strengthening honesty education as well as improving personality and quality development of college talents.
\end{abstract}

\section{Introduction}

Honesty, one of the basic social moral principles, has been impacted by the market economy and many other factors during China's social transformation period and it is currently faced with amounts of unprecedented challenges and threats. Many college students have weak consciousness of honesty and credit and thus behaving short of moral principle. College students are the precious talent resources and hope of our nation; they are the future of our motherland and charged with the important mission of constructing harmonious and well-off socialistic society. Therefore, to strengthen college students' honesty education and cultivate college students' credit quality is of great significance.

\section{Questionnaire subjects and methods}

With reference to the relevant domestic questionnaire and literature, and in combination with the actual questionnaire design about dishonesty problems of Jilin Agricultural University students, we carried on the questionnaire survey to students of Jilin Agricultural University. There were totally 480 questionnaires handed out, of which 480 questionnaires were designed for students and 463 ones were taken back, the questionnaire recovery rate was $96.5 \%$.

\section{Survey Results and Analysis}

Survey results show that the honesty features of Jilin agricultural university students are as follows.

\section{a. Features of Learning Honesty}

According to table 1, to the question “what's your idea about college students' cheating problem in exams?” Only $2 \%$ students didn't think they cheat in exams, and totally $74 \%$ students admitted they cheated sometimes and in a few cases, $24 \%$ answered they cheated frequently. And the result is that the mainstream of college students is honest in exams, but the number of $24 \%$ of the "frequently cheating" also catches our attention.

Table 1 What's your idea about cheating problem of college students?

\begin{tabular}{ccccc}
\hline Choices & Frequently & Sometimes & In a few cases & Never \\
\hline Proportion & $24 \%$ & $45 \%$ & $29 \%$ & $2 \%$ \\
\hline
\end{tabular}

b. Economic Honesty and Credit.

Table 2 shows that the mainstream of students' economic honesty awareness is positive and healthy, and the choices to the latter two cases account to $31 \%$, which indicates that students hold permissive attitude towards economic incredibility and they have no idea of national students' loan 
contract and are unaware of the contract relationship and the corresponding responsibility as well as the obligations reflected in the contract.

Table 2 What's your attitude towards students not paying loan on time?

\begin{tabular}{cccc}
\hline Choices & $\begin{array}{c}\text { Students } \\
\text { borrowed the } \\
\text { money, and } \\
\text { they are } \\
\text { supposed pay. }\end{array}$ & $\begin{array}{c}\text { It's understandable for } \\
\text { students' not paying } \\
\text { on time. }\end{array}$ & No idea. \\
\hline Proportions & $69 \%$ & $20 \%$ & $11 \%$ \\
\hline
\end{tabular}

\section{c. Job Hunting Dishonesty.}

According to table 3, in the survey of job hunting honesty, the latter three items account for 59\%, indicating there are nearly $60 \%$ students think job hunting dishonesty such as making false resume understandable and acceptable while hunting a job, it is true that most students tend to lose honesty principle when faced with decision whether to keeping honest or to seize the profit in real life.

Table 3 what's your idea about college students' dishonesty in job hunting?

$\begin{array}{lllll}\text { Choices } & \begin{array}{l}\text { It's } \\ \text { deceptive } \\ \text { behaviors. }\end{array} & \text { a } & \begin{array}{l}\text { It's } \\ \text { understanda } \\ \text { ble. }\end{array} & \begin{array}{l}\text { Students will lose } \\ \text { advantage if } \\ \text { don't cheat. }\end{array}\end{array}$

\begin{tabular}{lllll}
\hline Proportions & $41 \%$ & $41 \%$ & $13 \%$ & $5 \%$ \\
\hline
\end{tabular}

\section{d. Daily Interaction Honesty.}

As can be seen from table 4 nearly half of students in their daily life behave honestly and stick to honesty principle, but at the same time, nearly half of students behave at random, and having no instant honest behaviors.

Table 4 Whether can you be honest in real life interaction?

\begin{tabular}{|c|c|c|c|c|}
\hline Choices & $\begin{array}{l}\text { I surely can, } \\
\text { since it is } \\
\text { one of the } \\
\text { most } \\
\text { important } \\
\text { principles to } \\
\text { be a good } \\
\text { one. }\end{array}$ & $\begin{array}{l}\text { I can behave } \\
\text { honestly in } \\
\text { most } \\
\text { occasions, } \\
\text { but there're } \\
\text { exceptions. }\end{array}$ & $\begin{array}{l}\text { I often pay less } \\
\text { attention } \\
\text { behaving honestly, } \\
\text { and living up to } \\
\text { one's habit. }\end{array}$ & $\begin{array}{l}\text { Sometimes I } \\
\text { behave lacking } \\
\text { honesty to achieve } \\
\text { goals much more } \\
\text { significant. }\end{array}$ \\
\hline
\end{tabular}

\begin{tabular}{lllll} 
Proportions & $49 \%$ & $38 \%$ & $8 \%$ & $5 \%$ \\
\hline
\end{tabular}

\section{e. Online Integrity.}

Table 5 indicate that majority of college students hold doubtful attitude towards internet security and there is one third students thinking they spin lies when interact online, which shows that there is much less integrity online, and in return, it is less possible for college students to be honest online.

Table 5 Spinning lies when college students interact online.

\begin{tabular}{ccccc}
\hline Choices & Common. & Sometimes. & In a few cases. & No such situation. \\
\hline $\begin{array}{c}\text { Proportion } \\
\mathrm{s}\end{array}$ & $35 \%$ & $37 \%$ & $22 \%$ & $6 \%$ \\
\hline
\end{tabular}




\section{Discussion and Suggestions}

To define students as core of honesty education. The emphasis of college honesty education should be laid on students and the corresponding work should be carried out according to different characteristics displayed by students at their different stages and grades. Meanwhile the spirit of "self-discipline" should be advocated, and in facing the problem of lacking honesty students should be educated to make self-analysis and constantly strengthen their self-cultivation, set up correct outlook of world, outlook of life, values, as well as boost their sense of social responsibility and self-discipline ability. Colleges and universities should direct students to stick to the unity of knowledge and practice and then educate them to be strict to themselves on the little things around with purpose of turning value of honesty as students' internal demand and external behavior.

To define teachers as the leading and principal factor of honesty education. Teachers are the main part of schools, undertaking the mission of cultivating values, instructing knowledge and dispelling doubts, they are guide of young university students, teachers' ideology, ethical standards, educational philosophy, academic level and their words and actions have a profound effect on students' moral standing. Only if teachers act honestly, can students have the virtue of honesty. Therefore, colleges and universities should strengthen the ethical education of teachers and administrating parts to guarantee the honesty education effect.

To improve and perfect the credit and integrity system. One of the effective ways is to establish college students' comprehensive quality evaluation system, clarify the evaluation criteria and unify the evaluation standard as well as conduct a comprehensive objective evaluation of students with scientific methods. The second is to improve college students' credit archive construction and application system and comprehensively record students' actual performance, meanwhile, relate it to their academic performance to make them experience the value of being honest. The third is to establish incentive and punishment mechanism of honesty education, publish situation of students' honesty virtue regularly, award the good and give penalty to the bad to emphasize the modeling role of typical integrity and warn the negative effect of the counterexamples. [3]

To build honest campus surroundings. The sound honesty surroundings play a positive role in constructing students' honesty virtue. One is to combine honesty education with school culture construction in order to set honest college culture. The second is to use media to increase honesty propaganda and form the beneficial atmosphere. The third is to carry out campus cultural activities with the theme of being honest, such as creating "honesty month", doing integrity report and other activities alike, aiming to stimulate students' honesty and integrity quality, and eventually establish a good campus integrity circle.

\section{Summary}

All in all, college students' honesty and integrity education is a systematic social project, not only colleges and universities, but also families and the society as a whole should take responsibility and give full play to their irreplaceable advantages, thus the cooperative educational team can be formed to make a hopeful and brilliant talent training cause in nationwide of China.

\section{References}

[1] Dong Ya, Liao Xiaoming and Liu Wei. Status Investigation and In-depth Analysis of College Students'Learning Honesty. [J].Journal of Southwest University( JCR Social Science Edition),2008(3):60-66.

[2] Chen Xiaohui,Gao Chao. Survey and Analysis of College students Honesty [J]. Studies on Ideological Education, 2007(2):39-42 
[3] Huang Rongsheng, Wang Huamin. Honesty and Integrity: Focus of Moral Education among College Students on Socialist Concept of Honor and Disgrace. [J]. Journal of Southwest University( JCR Social Science Edition),2008(3):56-59. 